\title{
MUTED SCHOLARSHIP IN 1 CORINTHIANS: A GENDER-CRITICAL ENQUIRY
}

\author{
Johnathan Jodamus ${ }^{1}$ \\ Department of Religion and Theology \\ University of the Western Cape
}

\begin{abstract}
The First Letter to the Corinthians has provided a significant amount of material for scholars interested in studying how gender functions within Pauline writings and more generally in early Christianity. The body of work is rich and vast and draws largely on feminist theory and method as both an approach and an analytical lens. This paper argues that a careful application of gender-critical analysis has arguably been mute in such studies, despite the vast amount of feminist critique applied to these texts. Such muted scholarship has perpetuated a dialogical framework that juxtaposes studies of femininity and masculinity and has failed to take seriously the argumentative nature of rhetoric and explore important issues such as gender construction and representation within 1 Corinthians.
\end{abstract}

Key words: gender-critical; masculinity; femininity; construction(s); representation(s)

\section{Introduction $^{2}$}

Since its incorporation into the field of sociology in the early 1970s the concept of gender has become an important and hotly contested topic (Jackson and Scott 2002:1). The emergence of feminism in the 1970s led to the questioning of the androcentric view of the world which has existed in most cultures for as long as we can determine. It was crucial to the feminist project to respond to the essentialist postulation that existing gender differences between women and men are natural (Jackson and Scott 2002:1). The concept of gender was redefined "to emphasize the social construction of masculinity and femininity and the social ordering of the relations between women and men" (Jackson and Scott 2002:1). ${ }^{3}$ Gender was viewed as a dynamic social construct and not a direct derivative of biological sex, and more recently the intersectional character of gender insofar as it is influenced by other factors such as race, class, age, religion, social

\footnotetext{
Dr Johnathan Jodamus lectures in the Department of Religion and Theology at the University of the Western Cape, South Africa. jodamus@uwc.ac.za.

2 This article is extracted from a chapter of my unpublished $\mathrm{PhD}$ dissertation. See Jodamus (2015).

3 For a brief but insightful discussion of how the concept of gender developed within sociological theory from the prehistory of gender, that is prior to 1970, until the present time, see Jackson and Scott (2002:2-23). For further discussion of gender theory and an understanding of gender as the product of the social, cultural and psychological aspects obtained through the process of becoming a man or a woman in a specific society at a certain time, also see Stoller (1968) and Oakley (1972).
} 
relations, sexual preference, culture, and ethnicity, has also been noted (De Lauretis 1986:14; Schüssler Fiorenza 2007:159). ${ }^{4}$

Although this conception of gender correctly pointed to the socio-cultural construction of gender, it still presupposed that sex was dependent on fixed and "natural" anatomical and physiological characteristics (Jackson and Scott 2002:15). ${ }^{5}$ The presumption supporting the sex/gender differentiation has progressively been interrogated by feminist scholars such as Butler $(1990 ; 2002)$ and sociologists, as can be seen in the work of Jackson and Scott (2002). Current scholarship argues that the differentiation between sex and gender did not go far enough and has led to the investigation of both categories, sex and gender, as socio-cultural constructions (Jackson and Scott 2002:15). ${ }^{6}$

Although this new wave of investigation facilitates a more accurate social assessment of the distinction between women and men and confronts the logic of a natural binary divide between males and females, it nevertheless presupposes a binary, androcentric and heteronormative conceptualisation of sex and gender. As a construction created to be binary, this conceptualisation of sex and gender threatens to banish to the periphery or exclude all "other" sex and gender constructions, for example homosexuality, bisexuality, intersexuality and transsexuality, as well as those who identify as transgender and non-binary. Heteronormativity refers to the view that "institutionalized heterosexuality constitutes the standard for legitimate and prescriptive arrangements", an assumption that has led many scholars to question mainstream epistemologies of gender and sexuality and to call for a re-examination of such understandings (Ingraham 2002:79). ${ }^{7}$

4 Crenshaw (2011:25-42) first coined the term intersectionality within the context of critical legal studies and its specific interrogation of the plight and exclusion of "black women", whose "identity fixedness" as simultaneously black and women disqualified them from legal remedies. Since then this expression has been bolstered and may also be viewed as a critical analytical tool, a "thinking technology" (Lykke 2011:207-220) that subverts any binary notion of domination and zooms in on the multiplicity and interdependence of social factors that participate in creating and sustaining power relations that function as discourses in the creation of normativities, identities and social relations (Crenshaw 2011:221-233; Yuval-Davis 2011:155-169, 159).

5 Sex in this instance refers to the "biological aspects of a person such as the chromosomal, anatomical, hormonal, and physiological" structures. "It is an ascribed status in that a person is assigned to one sex or the other at birth" (Richardson 1981:5).

6 The basis for this kind of investigation may be traced back to the case study of Agnes, a male-to-female transsexual, conducted by Garfinkel (1967). In this study Garfinkel called biological sex into question as an essentialist feature of human experience and treated one's gender as an achievement or performance by the individual. This performance, however, is also based upon a deciphering of that performance by others which gives approval to one's gender representation. According to West \& Zimmerman (2002:43), the case of Agnes demonstrates what culture has concealed, namely "the accomplishment of gender". Also see Butler (1990:7) and her discussion of gender as "performative". For further discussion see Jackson \& Scott (2002:16) and West \& Zimmerman (2002:43-47).

7 Cf. Krondorfer (2010:4). Farley (2008:151-152) notes, "Cross-cultural anthropological studies have led some scholars ... to identify what they call a 'third sex' ... Gender for a third sex is not one (man or woman), and not 


\section{Gender shape shifting and its impact on 1 Corinthians}

This heteronormative and binary assumption regarding sex and gender construction has led many scholars to question mainstream epistemologies of gender and sexuality and to call for a re-examination of such understandings. ${ }^{8}$ These shifts in modern gender awareness and gender theory have significantly impacted and changed the face of New Testament studies in general, and Pauline studies in particular, especially since the advent of feminist criticism in the early 1970s (Wire 1990b: 220-223; Ehrensperger 2004:1). ${ }^{9}$ As women gradually sought leadership functions such as theologians, pastors, and biblical scholars, the argument about the role of women in the Christian canon and in the church proliferated in significance (Ackermann 1994; 1998; Dreyer 2002).

Certain passages in 1 Corinthians have frequently been isolated and employed in arguments to support the exclusion of women from ecclesial and academic leadership. In response feminist scholars have engaged critically with texts such as 1 Corinthians 11:2-16 and 1 Corinthians 14:34-35, seeking to centre women's experiences, and to discuss and reconstruct the role of women in early Christianity (Baumert 1996:174-182; Crocker 2004:4, 148; Ehrensperger 2004:2). Generally the inquiry into these gender texts has concentrated on either their content or their context (Penner and Vander Stichele 2005c:214; Conway 2008:8-11). The focus on interpreting the arguments Paul presents has been crucial in the analysis of their content, and the assessment of these arguments with regards to their possible effect on women, and in particular, their effect on the relationship between women and men. Analysis of the context of these texts has in turn focused on reconstructing the rhetorical situation in Corinth with an emphasis on understanding Paul's arguments (Penner and Vander Stichele 2005c:214).

When considering the biblical scholarship on 1 Corinthians, which ranges from exegetical studies, to socio-historical studies, to feminist studies, and the plethora of papers, monographs and books written on the various issues regarding women in 1 Corinthians, it soon becomes apparent that in one way or another, most of these studies strived to reconstruct "historical women" and their roles in early Christianity (May 2004; Mount 2005:313-340). ${ }^{10}$ Scholars have made numerous attempts to interpret the highly

always two (intersexed man and woman), but more often neither woman or man". For further discussion of other gendering possibilities see Farley (2008:152-156).

8 For an interesting discussion that seeks to subvert many of the essentialist notions regarding gender identity, see Cornwall, Harrison \& Whitehead (2008:1-19).

9 Among many others, also see Scroggs (1983); Hays (1986:184-215); Countryman (1988); D’Angelo (1990:141-161); Martin (1995a:332-355) and Horsley (2000b:1-16) for further discussion.

10 These studies are premised on a notion of the "material irreducibility of sex" and suggest a stable subject (Butler 1993:11). Contemporary gender critics, however, argue for the deconstruction of the term "woman" or "women" (and in the same vein the polar opposite "man" or "men") and suggest that there is no homogenous, stable subject (Butler 2011:x). Any search for a stable subject such as "women", therefore, is doomed to fail in the light of this gender-critical theory. It should be noted, however, that the materiality of bodies should not be disregarded in the light of this theorising and concern regarding the possible destabilising of the category of women to the point that it runs the danger of silencing the plight of women and the unique challenges that they face, is justified. 
contentious gendered texts of 1 Corinthians (Wire 1990b; Martin 2004). ${ }^{11}$ Most have opted to focus on analysing either 1 Corinthians 11:2-16 or 1 Corinthians 14:34-35. To date there is no scholarly agreement on these passages, and the field of New Testament studies is littered with many different and often contradictory interpretations (Thiselton 2000:800-838, 1150-1162; Paige 2002:217-220). One thing remains apparent, though, and that is that the discussion of gender in 1 Corinthians is still open for debate and consideration.

\section{A dialogical juxtaposing of gender discourse}

The literature reviewed for this paper indicates that the discourse of gender studies on 1 Corinthians has been situated in a dialogical framework that juxtaposes studies of femininity and masculinity. In fact, most of the work surveyed for this paper has in one way or another focused on exegetical reconstructions dealing with feminist or womanist studies that seek to reconstruct the role and importance of women in scripture (Ehrensperger 2004:19-42, 95-120; Penner and Vander Stichele 2005c:214-215). ${ }^{12}$ This literature also emphasises the evaluation of Paul's arguments; analyses of their implications for women, and more specifically whether or not Paul's arguments solicit a hierarchical or an egalitarian view of the relationship between women and men (Penner and Vander Stichele 2005c:214).

11 Also see Hooker (1963:410-416); Schüssler Fiorenza (1987:386-394; 2007:98-106); Walker (1989:75-88); Grudem (1991:425-468); BeDuhn (1999:295-320) to mention a few of the attempts by biblical scholars to interpret the gendered texts in 1 Corinthians.

12 This is understandable in the light of the fact that in the past so much was presented from a male perspective that left women completely out of the picture or simply replicated the views of the text. African-American women discovered that their agenda was not adequately represented by feminist theology, and as a result they developed womanist theology (Keane 1998:125). This phenomenon originated in North America among black American women who "did not feature prominently in the white middle class feminist agenda" (Keane 1998:131). For further discussion and for more insight about the origins of womanist theology see Walker (1983:xi-xii); Plaskow (1989:179-186); Baker-Fletcher (1995:183-196); Grant (1995:1); and Martin (1995:524). For a brief explication of African women's theology and hermeneutics see Phiri (1997:16; 2000:145-160); Ackermann (1998:349-357); Landman (1998:137-140); Oduyoye (1998:359-370); Dube and Kanyoro (2004). Owing to the intercultural and multivocal nature of feminist biblical discourses which take into account the plurality of women's experiences, there has been a proliferation of various strands of feminist theologies and hermeneutics in the past 30 years or so. However, my aim in this paper is not to give a history of the advent of feminist biblical inquiry, but rather to offer a literature review of gender studies on 1 Corinthians. For a helpful guide to the breadth of feminist biblical scholarship and a discussion that highlights the current changes and different strands of biblical feminisms that have developed in the last 30 years, see Isasi-Díaz (1994:88-104); Schüssler Fiorenza (2001:135-164, 183-186); Deifelt (2003:237-248); Dube (2003:54-72); Horsley (2003:297-317); Matthews, Kittredge and Johnson-DeBaufre (2003:1-14); Ehrensperger (2004:19-42, 95120); Tamez (2006); Hunt (2007:79-92). Two strands of current biblical feminism deserve to be noted due to their impact upon feminist theology, namely, postcolonial feminism and ecofeminism. For further discussion of postcolonial feminism, see Donaldson (1996); Dube (2000); Donaldson and Pui-lan (2002); Sugirtharajah (2003:133-140); Dube and Kanyoro (2004); Pui-lan (2005); Schüssler Fiorenza (2007:113-129); Marchal (2008:15-36). For further discussion of ecofeminism, see Gebara (2003:249-268); Ruether (2005:91-129) and Tucker (2007:129-138). 
Økland (2004:3) rightly states that in much feminist and "malestream" scholarship on Paul, and in particular on 1 Corinthians, the focus has been on Paul's view of women or what she terms the "quest for 'Paul's view of women". ${ }^{13}$ Økland (2004:3) further mentions that such an emphasis on women studies "will probably never succeed if we expect to find a unified view of women in his [Paul's] phallogocentric texts" ${ }^{14}$ In fact, Butler (1993: ix) shows that bodies move across boundaries and move boundaries, creating malleable "performative" subjects. This notion of an unstable, boundary-deviant subject contests the notion suggested by many early feminist scholars by their persistent pursuit of a stable, historical and somewhat pristine womanliness in their quest for the historical woman as if a homogenous construction of womanliness could be uncovered..$^{15}$

Studies that deal with issues of gender in 1 Corinthians may generally be classified in five main categories. These studies are often not presented as gender studies owing to the fact that gender-critical studies were only recently incorporated into New Testament biblical studies (Vander Stichele and Penner 2005a:287-310; Vander Stichele and Penner 2005b:1-30). Moore (2001:12-13) notes that,

Gender studies should not be confused with feminist studies. Gender studies does encompass feminist theory and criticism, and women's studies generally, but it also encompasses men's studies or, as it is less commonly (but more aptly) termed, masculinity studies .... The (unisex) umbrella term "gender studies" also offers shelter to lesbian and gay studies, and its obstreperous offshoot, queer theory-or so it is often assumed. ${ }^{16}$

Most studies that deal with gender issues in 1 Corinthians approach the discourse from a feminist-reconstructive perspective. In these instances only the particularities suggested by the text itself are treated as objects of analysis, with no real interest in what also lies between the lines. ${ }^{17}$ It would seem that often the fixed category "woman" has

Schüssler Fiorenza (2000:42) adopted the expression "malestream" from feminist theorists as a descriptive term, "since most of our cultural and religious texts, traditions, and institutions have been and are still determined by elite (white) men". Also see Schüssler Fiorenza (1984a; 1985). For other contemporary scholars who also use this neologism, see Horsley (2000b:7-9); Hewitt (2003:454) and Ehrensperger (2004:2).

My emphasis. This assertion by Økland (2004:3) coheres with current scholarship which maintains that gender categories are not homogeneous (Jackson and Scott 2002b:21; Cornwall, et al. 2008:14).

15 Scholars like Butler (1993:4) call into question the notion of sex as an a priori and not also a cultural construction such as gender. It should be mentioned, however, "the category of women does not become useless through deconstruction, but becomes one whose uses are no longer reified as 'referents,' and which stand a chance of being opened up, indeed, of coming to signify in ways that none of us can predict in advance. Surely, it must be possible both to use the term, to use it tactically even as one is, as it were, used and positioned by it, and also to subject the term to a critique which interrogates the exclusionary operations and differential power-relations that construct and delimit feminist invocations of "women"” (Butler 1993:5). To deconstruct the term "women" is not, therefore, to do away with the term as useful, according to Butler (1993:5).

16 For further discussion of queer theory and queer theologies see Goss (2009:137-145); Schneider (2009:63-76).

17 Addressing what lies between the lines is outside the scope of this article. This article contributes on two primary levels: the first being a helpful review of scholarship on the exploration of the theme of gender in 1 Corinthians 
obscured further investigations of engendered relations of power. These studies may be categorised in the following manner. First, some scholars have opted to interpret the gendered passages of 1 Corinthians as non-Pauline interpolations (Weiss 1977:342). ${ }^{18}$ Such studies often maintain that the texts embody an understanding of women incongruous with Paul's own views concerning women (Murphy-O'Connor 1976:615621; Fee 1987:697-705). ${ }^{19}$

Second, studies on gender in 1 Corinthians have often been devoted to particular topics that deal with gender issues. The topics that are usually investigated are head coverings (Engberg-Pedersen 1991:679-689; Thiselton 2000:800-828; Martin 2004:75$84),{ }^{20}$ the silencing of women (Baumert 1996:195-198; Arichea 2004:460-469), and women prophesying (Wire 1990b:1, 63-67, 181-192; Arichea 2004:465). All three are related to the issue of women's subordination to men and arise from the study of 1 Corinthians 11:2-16 and 14:34-35. ${ }^{21}$ This type of investigation usually takes the form of exegetical analysis of certain gendered texts within the discourse of 1 Corinthians 11 and 14. In recent years the field of New Testament studies has been bombarded with many

the second being a fusing of gender-critical theory and hermeneutics. Concerning the latter, in terms of what such a fusion might look like and how it could be applied to the Corinthian text, see Jodamus (2016; 2017).

18 For further discussion also see Barrett (1968:330, 332-333) who mentions other scholars who follow this path of investigation. Cf. Conzelmann (1975:246); Fee (1987:705); Thiselton (2000:1150).

19 For further discussion also see Murphy-O’Connor (1988:265-274); Wire (1990b:149-152, 229-232); Witherington (1995:288); Arichea (2004:460-462); Crocker (2004:153, 157-162); Crossan (2004:70-123); Økland (2004:149-151) and Mount (2005:313-340).

20 For further discussion also see Hooker (1963:410-416); Murphy-O’Connor (1988:265-274); Thompson (1988:99-115); Wire (1990b:220-223); Grudem (1991:425-468); Jervis (1993:231-246); Martin (1995b:229 249); Witherington (1995:232-240); Baumert (1996:182-194); BeDuhn (1999:297-308); Winter (2003:7796); Crocker (2004:153); Loader (2004:99-104); Merkle (2006:527-548) and Lakay (2010:6-36). In his analysis Murphy-O'Connor (1988:265-274; 1980:483) offers an exegesis of 1 Cor. 11:2-16. His investigation differs from other similar exegetical analyses in that it takes into account both women and men as opposed to focusing solely on women in the passage with men merely being dismissed as "a background in contrast with which woman's situation and obligation can be more sharply described" (Murphy-O'Connor 1988:266). Murphy-O'Connor (1980) argues that the problem in Corinth that Paul addresses in 1 Cor. 11:2-16 involves both men and women and the issue of how they dressed their hair. His interpretation purports that "head" should be interpreted as "source" in 1 Cor. 11:3 and maintains that the issue of men's hair/dress was just as much a problem as that of women in the church. Also see Thiselton (2000:805) who follows Murphy-O'Connor (1980) in asserting that Paul addresses not only the way women dressed, but also the way men dressed.

21 Even under these broad topical headings scholars differ tremendously in interpretation. An example of this can be found in the interpretation of 1 Cor. 11:2-16 and whether or not Paul is addressing married women or women in general. Cf. Hayter (1987); BeDuhn (1999:295-320); Paige (2002:217-242) and Winter (2003:77-96). Scholars are divided on the topic of head covering in 1 Cor. 11 as to what is referred to when Paul states that women should cover their heads. Some scholars postulate that the women's hair itself was the covering and, therefore, women should not wear their hair loose during worship gatherings (Baumert 1996:183, 186; Cosgrove 2005:675-692). Other scholars maintain that Paul is referring to a veil of some kind that women should wear (Witherington 1995:233; Arichea 2004:462-464). Also see Martin (2004) who argues that a woman's unbound hair was synonymous with her genitalia according to ancient conceptions of physiognomy. 
such studies, dealing with the same texts investigated from different methodological vantage points, or using the same methodology with diverse and often contradictory results (Engberg-Pedersen 1991:679; Cosgrove 2005:675-692).

Third, studies on gender in 1 Corinthians have often focused on the study of women in early Christianity and in antiquity more broadly. Such studies deal primarily with reconstructing by means of ancient sources the role and status of women in the period of early Christianity, focusing on issues such as women leadership in early Christianity and more broadly on their leadership in general in antiquity (Kraemer and D'Angelo 1999; Osiek and Madigan 2005; Osiek, MacDonald and Tulloch 2006). ${ }^{22}$

Fourth, another less prominent view for understanding the gender passages of 1 Corinthians has been to suggest that the passages contain the opinions of the Corinthian Christians themselves, and not Paul's views. According to this hypothesis, Paul mentions the opinions of the Corinthian Christians in the gendered passages of 1 Corinthians, not because he agrees with them, but rather because he wants to refute them (Walker 1975:94-110; Trompf 1980:196-215). ${ }^{23}$

Fifth, a handful of scholars have analysed 1 Corinthians with an emphasis on the "male issue" (Oster 1988:481-505), or rather, with an emphasis on investigating men in 1 Corinthians (Murphy-O’Connor 1980:483; 1988:265-274). ${ }^{24}$ Only very recently have some New Testament studies on 1 Corinthians emerged with a keen interest in the issue of masculinity(ies) in 1 Corinthians using gender-critical approaches (Moore 1996; Anderson, Moore and Kim 2003:36-37; Mayordomo 2008:99-115). ${ }^{25}$

\section{Grappling with gender construction(s) and representation(s) in 1 Corinthians}

As noted above, many scholars have undertaken exegetical studies of certain problematic gender texts in 1 Corinthians. This has given rise to copious amounts of scholarly work in the form of journal articles and books emphasising the subject of "women". With the

22 For a discussion of women in early Christianity, also see Brooten (1982); Witheringon (1992); Torjesen (1993); Kloppenborg (1996); MacDonald (1996); Osiek and Balch (2003); Taylor (2003); Winter (2003) and Crocker (2004).

23 For further discussion see Odell-Scott (1983:90-93; 1991:179-183); Walker (1983:101-112) and Paige (2002:219).

24 Oster (1988:481-505) in his work emphasises the "male issue" in 1 Cor. 11:3-16.

25 Cf. Conway (2008:8-11); and Marchal (2014:93-113). A gender-critical approach takes seriously the argumentative nature of rhetoric and focuses on issues such as gender construction and identity within a text (Økland 2004:1-5; Penner and Vander Stichele 2005c:217-219; Vander Stichele and Penner 2009:4-7, 25). Most New Testament studies on masculinity have focused on masculinity in the gospels, as may be seen in the bibliography on New Testament masculinity studies provided by Anderson, Moore and Kim (2003:23-42). Cf. Martin (2006); and Krondorfer (2009a:184-186). For a discussion which is focused on uncovering the masculinity of Paul in 1 Corinthian see Clines (2003:181-192). Similarly, for a discussion of Paul's masculinity with regards to 2 Corinthians, see Harrill (2001:189-213); and Larson (2004:85-97). Also see the study by Kahl (2000:37-49) which focuses on masculinity in Gal. 3:28. Across the humanities and social sciences, the writings on masculinity(ies) are already enormous; for a bibliography on ancient and contemporary masculinities, see, among many others, Gilmore (1990); Boyd (2009:51-55); Boyarin (2009:79-95) and Krondorfer (2009b:421436; 2010). 
advent of the women's liberation movement and its impact on theology in the early 1970's, and the emergence of feminist interpretations in biblical studies, even more work began to emerge with a primary focus on re-constructing women's identities in scripture and the role of women in the ancient world (Daly 1968; Ruether 1974). ${ }^{26}$ The dominant hermeneutical framework posited under the feminist wave of scholarship was a "hermeneutics of suspicion" (Schüssler Fiorenza 1984a; Gebara 2003:250). ${ }^{27}$ One of the pioneering scholars supporting this tradition of feminist hermeneutics, is Schüssler Fiorenza (2000), ${ }^{28}$ who combines historical criticism with a rhetorical hermeneutics of suspicion in her approach to biblical studies. ${ }^{29}$ This method of interpretation is applied to biblical texts in an effort to reveal the concealed and muted history of women in patriarchal and "kyriarchal" texts (Schüssler Fiorenza 1984a; 1984b). Feminist scholars have, therefore, refined the dominant theological matters from a feminist vantage point in order to progress to a theology that will buttress the liberation of women (Ehrensperger 2004:21).

Although the above-mentioned studies are highly informative and were much needed, it seems that reconstructive hermeneutics has become the dominant framework for investigation of gender in 1 Corinthians. Such studies focused primarily on women and women related issues and failed to consider that discourse itself is gendered in the light of the ancient Mediterranean concepts of gender (Økland 2004; Conway 2008). These studies have, therefore, failed to investigate how gender is constructed by the discourse itself. In fact, currently, most research pertaining to gender and 1 Corinthians focuses primarily on the study of women. Schüssler Fiorenza (2001:5) observes,

Malestream historical criticism, so also ideology criticism as well as postcolonial and cultural biblical criticism have for the most part not made wo/men subjects of interpretation, connected intellectuals, or historical agents central to their theoretical frameworks. Neither have they sufficiently recognized the importance of gender analysis for biblical studies or developed an ethics of interpretation that always takes wo/men's experience into account when analyzing social location and the operations of power within discourse.

Indeed, postcolonial and cultural criticism is rightly judged by Schussler-Fiorenza for its lack of attention to wo/men - but I argue that a focus on women as a stable category, as is the case in much of feminist discourse, is equally unhelpful. Apart from ignoring the intersectional operations of power such as race and class on the unstable category of women, it also largely ignores those who are positioned as women socially and politically (slaves, poor men, gay men etc.). The nomenclature wo/men, coined by

Also see Daly (1973). For further discussion that gives a brief history of the emergence of feminist biblical inquiry and contemporary advances in this field, see Castelli (1994:73-98); Segovia (2003b:1-32) among others.

27 For further discussion of this hermeneutical framework see Schüssler Fiorenza (2001:175-177).

28 Cf. Robbins (2002c:112).

29 For a careful articulation of the methodology used by Schüssler Fiorenza and a brief discussion of her scholarship, see Schüssler Fiorenza (1985:55-63); Matthews, Kittredge and Johnson-DeBaufre (2003:1-14). 
Schussler Fiorenza, calls for recognition of the nuance, but is, I argue, largely ignored in feminist scholarship. Recognising the importance of gender analysis that takes gender as a serious analytic category for biblical studies (Boyd 2009:53; Krondorfer 2009:xii), would have enriched the studies reviewed in the purview of this paper, which have largely not focused on the construction(s) and representation(s) of male and female gender identity(ies) in 1 Corinthians. These types of analyses presuppose gender construction(s) and representation(s) or rather, gendered issues, but instead of grappling with these phenomena in particular, they analyse the results or symptoms of Paul's gender construction(s) and not his actual construction(s) and representation(s) of gender. The discussion of 1 Corinthians along such investigative lines of inquiry has obscured the perspective of the discourse of 1 Corinthians as persuasive rhetoric that constructs and enforces certain gendered identities.

As mentioned earlier, within the framework of New Testament studies, the study of gender is relatively new in comparison to other fields of study such as Classical Studies (Pomeroy 1975; Moore and Anderson 1998:249-251). ${ }^{30}$ In the last 25 years Classical Studies scholars focused considerable attention on the construction(s) of gender in ancient Greek and Roman antiquity (Gleason 1990:389-416; Winkler 1990b). This type of research has led to key questions concerning the conceptualisation of femininity(ies) and masculinity(ies) during this period (Halperin 1990:135-170; Satlow 1994:1-25). Despite the research in Classic Studies concerned with femininities and masculinities, these have not emerged in New Testament scholarship. New Testament scholars have been rather tardy in their application of gender-critical studies to the analysis of biblical texts (Glancy 1994:34-50; 2004:99-135; Larson 2004:85-97). Besides applying classical gender-critical knowledge to investigate socio-cultural aspects that inform their analyses of ancient Mediterranean culture, not many New Testament scholars have applied gender theory and gender-critical analysis to their investigations of biblical texts (Moore 2001; Clines 2003:181-192) ${ }^{31}$ And only a handful of New Testament scholars have used gender theory and gender-critical approaches to investigate 1 Corinthians (Økland 2004:6-38, 168-223; Penner and Vander Stichele 2005c:214-237; Lakey 2010:97-135, 136-179). ${ }^{32}$

\section{Conclusion}

Although previous studies on the gendered texts of 1 Corinthians have been located in a dialogical framework that juxtaposes the study of femininity and masculinity, most of the scholarly attention of this type of research has concentrated on "femininity", meaning works directed towards feminist or womanist studies. Some New Testament biblical scholars recently demonstrated the benefits of shifting the focus of analysis from arguments and analyses based largely, if not solely, on reconstruction of socio-historical

30 Pomeroy (1975) was one of the first classical scholars to do work on women in antiquity. Moore and Anderson (1998:249) note that "[h]er work was the first full-length study of this generation to take the question of women in antiquity seriously".

31 Also see Stowers (1994:42-82); Martin (1995a:332-355); Dube (2003:54-72); Vander Stichele (2005b; 2005a); Marchal (2008; 2014:93-113); Thurman (2007:185-230); DeBaufre and Nasrallah (2011:161-174).

32 Cf. Ivarsson (2007:163-184); Bird (2011:177, 180, 181); Marchal (2014:93-113). 
circumstances, to gender-critical approaches that take the argumentative nature of rhetoric seriously and explore issues such as gender construction(s) and identity(ies) (Moore 1996; Kittredge 2000:103-109). ${ }^{33}$ The latter approach places emphasis on the discourse itself and seeks to understand the discourse as argument aimed at persuasion as opposed to placing emphasis on the subjects of the rhetorical argument such as veiling, women who speak in tongues or prophecy, and women in general, as has been the norm in Biblical Studies for far too long. From this rhetorical vantage point Paul is identified as a rhetorician engaged in the art of persuasion as opposed to one writing authoritatively as a messenger of God. The latter view of Paul runs the risk of seeing Paul's words as authoritative without taking into account that the discourse is a rhetorical construction, and that Paul is engaged in the ancient art of rhetorical persuasion. Former historicalcritical interpretations of Paul's arguments in 1 Corinthians have relied on reconstructive socio-historical approaches that ultimately shield "Paul's rhetorical strategy by resisting the 'decoding' of terms, concepts, and strategic modes of argumentation he uses" (Penner and Vander Stichele 2005c:217).$^{34}$ In these types of approaches the emphasis is on understanding "Paul's arguments from a decidedly historical perspective" (Vander Stichele and Penner 2005a:288).

The shift in approach to a gender-critical approach has also resulted in a shift in focus from the historical issues at stake in the analysis of texts to enquiry into more important issues of gender construction(s) and identity(ies), which are central to "ancient rhetorical theories of proper comportment and oratorical display" (Penner and Vander Stichele 2005c:219). ${ }^{35}$ Økland (2004:1) in her analysis of 1 Corinthians 11-14 demonstrates that Paul's exhortations regarding women's ritual roles and ritual clothing in 1 Corinthians 11-14 structure and gender the Christian gathering as a specific type of space, a "sanctuary space", constructed through ritual. Therefore, the central point of Paul's rhetoric in 1 Corinthians 11-14 is not women's veiling or covering, but rather the production and maintenance of a gendered order of the ritual space in the community (Økland 2004:1). ${ }^{36}$ Such a gender-critical engagement of the text allows for a far more

33 Also see Økland (2004) and Conway (2008). Økland (2004:31-35) makes use of what she terms a "ritual approach" to investigating 1 Cor. 11-14 which she argues allows her to focus more clearly on the ancient discourse of gender and ritual and how ritual constructs gendered spaces. The "ritual approach" as posited by Økland (2004:35) allows her to glean gendered nuances from the contemporaneous Corinthian texts, and in particular, archaeological texts. This in turn allows for a comparison of "utterances concerning women in the texts of Corinthian cults, rituals and sanctuaries including the ekklesia, and thus finding traces of a discourse on 'women' and ritual space where cultic models of the female are related to the space the ritual takes place within". See for example Wire (1990b); Martin (1995b) and Winter (2003).

35 I am aware of the need to be cautious of this distinction because many of the gender-critical approaches that are used in the analysis of biblical material depart from a historical critical perspective. The difference, however, is that the type of historiography is different - it no longer simply and only enquires as to "what" or "whether something" has happened, but investigates the socio-historical relations of power, specifically as they pertain to gender, that underlie the text.

36 Her understanding of 1 Cor. 11-14 is based on an investigation of an assortment of material texts, while the discourse of sanctuary space is grounded on notions of ancient Mediterranean gender discourse. This highlights how space in antiquity was gendered, primarily as it was related to formulations of the order of the cosmos 
comprehensive forum for dialogue by concentrating on the "interrelationship of the discursive identities of male and female 'players' created in and through Pauline argumentation" (Vander Stichele and Penner 2005:291). Shapiro (2003:517), who also implements a gender sensitive approach, or what she terms "reading for gender", in her investigation of Jewish philosophical texts, notes that "reading for gender does not mean either reading for women or as a woman". She states,

To read for metaphors of "woman", "body", "gender relations" or "sexuality" is not to read for some actual woman or women that the text, somehow, represents. Nor does reading for gender mean reading as an "essentialized" woman reader who, as a woman, can (supposedly) locate the "feminine" stratum of the text. Rather, it is to read for constructions and performances of gender in these texts with an interest in the intellectual and cultural labor these tropes enact. (Shapiro 2003:518)

Similarly, my interest is in an examination of how gender is constructed and represented through the argumentative discourse of the text and also how Paul constructs his gendered identity in the text. Penner and Vader Stichele (2005c:219) too display the value in moving beyond "mirror readings" of Pauline literature to examining the text as argument by focusing on the argumentative strategies employed by Paul to persuade his audience. ${ }^{37}$ Contemporary biblical scholars also demonstrate the fact that the ancient Mediterranean civilisation was constructed and orchestrated on a cosmic gender structure that was viewed as natural and was integrated into all areas of life so that gender strictly demarcated all aspects of life in ancient Mediterranean society (Stegemann and Stegemann 1999:361; Økland 2004:1). Dube (2003:60) observes,

It is a feminist tradition in biblical studies to focus on passages that feature women, as attested by our current women/feminist commentaries. No doubt the method has furthered the feminist struggle by highlighting women as both victims and agents of liberation in the text, but the approach seems to imply that passages that do not feature women characters are less important to the feminist search for justice. The approach seems to neglect the fact that gender constructions pervade all social spheres of life.

(Økland 2004:2). Although Økland (2004:1) mentions that she is cautious not to reproduce the misleading notion "that only women are gender", she still, however, focuses most of her attention in her analysis primarily on women in particular. See, for example, Økland (2004:69), where she comments on how gender in the ancient Mediterranean world was constructed through ritual space, but her analysis focuses solely on female gender construction instead. Because she does not focus on men and women in the text, it seems that she primarily produces work on women and not gender in 1 Corinthians.

37 Lyons (1985) coined this term and it is also used by Vorster (1994:127-145) in the context of the letter to the Romans, more specifically in the deployment of the category "rhetorical situation". According to Penner and Vander Stichele (2005c:217) "mirror readings" should be understood as "the technique of reading from what is explicitly argued to that which is allegedly being responded to in the text, attempting to draw out the unknown by reversing the logic of the stated argument". Cf. Wire (1990b:12-38); Penner and Lopez (2012:33-50). 
Because Paul was structured by and functioned within the larger discourses of the ancient Mediterranean sex and gender system(s), one cannot comprehend the gendered rhetoric of 1 Corinthians without recourse to its interconnections with ancient gender discourse in general. Furthermore, because of the nature of gender in the ancient world, when Paul engages in persuasion through the discourse of 1 Corinthians, gender construction(s) and representation(s) are precisely what is at stake. One cannot, therefore, comprehend the rhetoric of 1 Corinthians without understanding the gendered nature of the discourse. ${ }^{38}$ Doing so would simply amplify an already muted gender critical scholarship and would perpetuate the juxtaposing of femininity and masculinity as has been normative in studies related to 1 Corinthians in particular and New Testament biblical studies in general.

\section{BIBLIOGRAPHY}

Ackermann, Denise M. 1994. Faith and feminism: Women doing Theology. In J. de Gruchy and C. Villa-Vicencio (Eds), Doing Theology in context: South African perspectives (Vol. I). Cape Town, South Africa: David Philip Publishers, 197-211.

-. 1998. Feminist and womenist hermeneutics. In Simon Maimela and Adrio König (Eds), Initiation into theology: The rich variety of theology and hermeneutics. Hatfield, Pretoria: JL van Schaik Publishers, 349-357.

Anderson, Janice Capel, Moore, Stephen D. and Kim, Seong Hee. 2003. Masculinity studies: A classified bibliography. In Stephen D. Moore and Janice Capel Anderson (Eds), New Testament masculinities. Atlanta: Society of Biblical Literature, 23-42. Arichea, Daniel C. 2004. The covering on the woman's head: Translation and theology in 1 Corinthians 11.2-16, The Bible Translator 55(4 October):460-469.

Baker-Fletcher, Karen. 1995. Womanism, Afro-centrism and the reconstruction of black womanhood. In Jacquelyn Grant (Ed.), Perspectives on womanist theology. Atlanta, GA: ITC Press, 183-196.

Barker, Chris. 2002. Television, globalization and cultural identities. Buckingham, Philadelphia: Open University Press.

Barrett, C.K. 1968. A commentary on the First Epistle to the Corinthians. New York: Harper \& Row Publishers.

Baumert, Norbert S.J. 1996. Woman and man in Paul: Overcoming a misunderstanding. Collegeville, MINN: Liturgical Press.

BeDuhn, Jason David. 1999. "Because of the angels": Unveiling Paul's anthropology in 1 Corinthians, JBL 118:295-320.

Boyarin, Daniel. 2009. Unheroic conduct: The rise of heterosexuality and Jewish masculinity. In Björn Krondorfer, Men and masculinities in Christianity and Judaism: A critical Reader. Comp. Björn Krondorfer. Pp. 79-95. London, UK: SCM Press.

Boyd, Stephen B.

2009Trajectories in Men's Studies in Religion: Theories, Methodologies, and Issues. In Men and Masculinities in Christianity and Judaism: A Critical Reader. Comp. Björn Krondorfer. Pp. 51-55. London, UK: SCM Press. 
Brooten, Bernadette J. 1982. Women leaders in the ancient synagogue. Chicago, Calif: Scholars Press.

Butler, Judith. 1990. Gender trouble: Feminism and the subversion of identity. London: Routledge.

—. 2002. Performative subversions. In Stevi Jackson and Sue Scott (Eds), Gender: A sociological reader. London: Routledge, 48-50.

Castelli, Elizabeth A. 1994. Heteroglossia, hermeneutics and history: A review essay of recent feminist studies of early Christianity, The Journal of Feminist Studies in Religion 10(2):73-98.

Clines, David J.A. 2003. Paul, the invisible man. In Stephen D. Moore and Anderson, Janice Capel (Eds), New Testament masculinities. Atlanta: Society of Biblical Literature, 181-192.

Cornwall, Andrea, Harrison, Elizabeth and Whitehead, Ann. 2008. Gender myths and feminist fables: The struggle for interpretive power in gender and development. Malden, MA: Blackwell, 1-19.

Cosgrove, Charles H. 2005. A woman's unbound hair in the Greco-Roman world, with special reference to the story of the "Sinful Woman" in Luke 7:36-50, JBL 124(4):675-692.

Countryman, L. William. 1988. Dirt, greed and sex: Sexual ethics in the New Testament and their implications for today. Philadelphia: Fortress Press.

Crocker, Cornelia Cyss. 2004. Reading 1 Corinthians in the twenty-first century. New York, NY: T\&T Clark International.

Crossan, John Dominic and Reed, Jonathan L. 2004. In search of Paul: How Jesus's apostle opposed Rome's empire with God's words and world. A new vision of Paul's words and world. New York: HarperSanFrancisco.

D' Angelo, Mary Rose. 1990. Women in Luke-Acts: A redactional view, Journal of Biblical Literature 109:141-161.

Daly, Mary. 1968. The Church and the second sex. New York, NY: Harper and Row.

-.1973. Beyond God the Father: Toward a philosophy of women's liberation. Boston: Beacon Press.

Davies, Bronwyn. 2002. Becoming male or female. In Stevi Jackson and Sue Scott (Eds), Gender: A sociological reader. London: Routledge, 280-289.

De Beauvoir, Simone. 2009. The second sex. Constance and Malovany-Chevallier Borde, Sheila. New York: Alfred A. Knopf.

Deifelt, Wanda. 2003. Feminist theology: A key for women's citizenship in the church. In Fernando F. Segovia (Ed.). Toward a new heaven and a new earth: Essays in honor of Elisabeth Schüssler Fiorenza. Maryknoll, NY: Orbis, 237-248.

Donaldson, Laura E. (Ed.). 1996. Postcolonialism and scriptural reading, Semeia 75.

Donaldson, Laura E. and Pui-lan, Kwok. 2002. Postcolonialism, feminism, \& religious discourse. New York: Routledge.

Dreyer, Yolanda. 2002. Women and leadership from a pastoral perspective of friendship, Hervormde Teologiese Studies 58(1):43-61.

Dube, Musa W. 2000. Postcolonial feminist interpretation of the Bible. St. Louis, MO.: Chalice. 
- Musa. 2003. Rahab says Hello to Judith: A decolonizing feminist reading. In Fernando F. Segovia (Ed.). Toward a new heaven and a new earth: Essays in honor of Elisabeth Schüssler Fiorenza. Maryknoll, NY: Orbis, 54-72.

Dube, Musa W. and Kanyoro, Musimbi. 2004. Grant me justice: HIV/AIDS \& gender readings of the Bible. Maryknoll, NY: Orbis.

Ehrensperger, Kathy. 2004. That we may be mutually encouraged: Feminism and the new perspective in Pauline studies. New York: T\&T Clark.

Engberg-Pedersen, Troels. 1991. 1 Corinthians 11:16 and the character of Pauline exhortation, JBL 110(1):679-689.

Farley, Margaret A. 2008. Just love: A framework for Christian sexual ethics. New York, NY: Continuum.

Fee, Gordon D. 1987. The First Epistle to the Corinthians. Grand Rapids, MI: Eerdmans.

Gebara, Ivone. 2003. A feminist theology of liberation: A Latin American perspective with a view toward the future. In Fernando F. Segovia (Ed.). Toward a new heaven and a new earth: Essays in honor of Elisabeth Schüssler Fiorenza. Maryknoll, NY: Orbis, 249-268.

Gilmore, D.D. 1990. Manhood in the making: Cultural concepts of masculinity. New Haven: Yale University Press.

Glancy, Jennifer A. 1994. Unveiling masculinity: The construction of gender in Mark 6:7-29, Biblical Interpretation 11:34-50.

-. 2004. Boasting of beatings (2 Corinthians 11:23-25), JBL 123:99-135.

Gleason, Maud W. 1990. The semiotics of gender: Physiognomy and self-fashioning in the second century C.E. In David M. Halperin, John J. Winkler and Froma I. Zeitlin (Eds). Before sexuality: The construction of erotic experience in the ancient Greek world. Princeton, New Jersey: Princeton University Press, 389-416.

Goss, Robert E. 2009. Transgression as a metaphor for queer theologies. In Björn Krondorfer, Men and masculinities in Christianity and Judaism: A critical reader. London, UK: SCM Press, 137-145.

Grant, Jacquelyn. 1995. Perspectives on womanist theology. Atlanta, GA: ITC Press.

Grudem, Wayne A. 1991. The meaning of kephale ("head"): A response to recent studies. In John Piper and Wayne Grudem (Eds). Recovering Biblical manhood and womanhood: A response to evangelical feminism. Wheaton, IL: Crossway, 425468.

Halperin, David M. 1990. Why is Diotima a woman? Platonic eros and the figuration of gender. In David M. Halperin, John J. Winkler and Froma I. Zeitlin (Eds). Before sexuality: The construction of erotic experience in the ancient Greek world. Princeton, New Jersey: Princeton University Press, 257-308.

Harrill, J. Albert. 2001. Invective against Paul [2 Cor 10:10], the physiognomics of the ancient slave body and the Greco-Roman rhetoric of manhood. In Yarbro A. Collins and M.M Mitchell (Eds). Antiquity and humanity: Essays on ancient religion and philosophy presented to Hans Dieter Betz on his 70th birthday. Tubingen: Mohr Siebeck, 189-213.

Hays, Richard. 1986. Relations natural \& unnatural: A response to John Boswell's exegesis of Romans 1, Journal of Religious Ethics 14:184-215. 
Hayter, Mary. 1987. The new Eve in Christ: The use and abuse of the Bible in the debate about women in the church. London: Latimer Trend and Company.

Hewitt, Marsha Aileen. 2003. Dialectic of hope: The feminist liberation theology of Elisabeth Schüssler Fiorenza as a feminist critical theory. In Fernando F. Segovia (Ed.). Toward a new heaven and a new earth: Essays in honor of Elisabeth Schüssler Fiorenza. Maryknoll, NY: Orbis, 443-458.

Hooker, Morna. 1963. Authority on her head: An examination of 1 Cor 11:10, NTS 10:410-416.

Horsley, Richard A. 2000. Introduction: Krister Stendahl's challenge to Pauline studies. In Richard A. Horsley (Ed.), Paul and politics: Ekklesia, Israel, imperium, interpretation. Essays in Honor of Krister Stendahl. Harrisburg, PA: Trinity Press International, 1-16.

- 2003. Feminist scholarship and postcolonial criticism: Subverting imperial discourse and reclaiming submerged histories. In Shelly Matthews, Cynthia Briggs Kittredge and Melanie Johnson-Debaufre (Eds). Walk in the ways of wisdom: Essays in honor of Elisabeth Schüssler Fiorenza. Harrisburg, PA: Trinity Press International, 297-317.

Hunt, Mary E. 2007. Unfinished business: The flowering of feminist/womanist theologies. In Rosemary Radford Ruether (Ed.), Feminist theologies: Legacy and prospect. Minneapolis, MN: Fortress, 79-92.

Ingraham, Chrys. 2002. The heterosexual imaginary. In Stevi Jackson and Sue Scott (Eds), Gender: A sociological reader. London: Routledge, 79-84.

Isasi-Díaz, Ada María. 1994. The task of Hispanic women's liberation theology Mujeristas: Who we are and what we are about. In Ursula King (Ed.), Feminist theology from the Third World. Maryknoll, NY: Orbis, 88-104.

Jackson, Stevi, and Scott, Sue (Eds). 2002a. Gender: A sociological reader. London: Routledge.

- 2002. Introduction: The gendering of Sociology. In Stevi Jackson and Sue Scott (Eds), Gender: A sociological reader. London: Routledge, 1-26.

Jervis, Ann L. 1993. "But I want you to know...": Paul's Midrashic intertextual response to the Corinthian worshipers (1 Cor 11:2-16), JBL 112(2):231-246.

Jodamus, J. 2015. An investigation into the construction(s) and representation(s) of masculinity(ies) and femininity(ies) in 1 Corinthians. Unpublished PhD dissertation, University of Cape Town.

- 2016. Gendered ideology and power in 1 Corinthians, Journal of Early Christian History (JECH) 6.1 (2016):1-30.

- 2017. Paul, the "real" man: Constructions and representations of masculinity in 1 Corinthians, Journal of Gender and Religion in Africa 23, 2 (2017):68-94.

Keane, Marie-Henry. 1998. Feminist and womenist theology. In Simon Maimela and Adrio König (Eds), Initiation into theology: The rich variety of theology and hermeneutics. Hatfield, Pretoria: JL van Schaik Publishers, 121-134.

Kittredge, Cynthia Briggs. 2000. Corinthian women prophets and Paul's argumentation in 1 Corinthians. In Richard A. Horsley (Ed.), Paul and politics: Ekklesia, Israel, imperium, interpretation: Essays in honor of Krister Stendahl. Harrisburg, PA: Trinity Press International, 103-109. 
Kloppenborg, John S. 1996. Egalitarianism in the myth and rhetoric of Pauline churches. In Reimagining Christian origins: A colloquium honoring Burton L. Mack. Valley Forge, PA: Trinity Press International, 247-263.

Kraemer, Ross Shepard and D'Angelo, Mary Rose (Eds). 1999. Women and Christian origins. New York, NY: Oxford University Press.

Krondorfer, Björn. 2009a. Men and masculinities in Christianity and Judaism: A critical reader. London, UK: SCM Press.

—. 2009b. Who's afraid of gay theology? Men's studies, gay scholars, and heterosexual silence. In Björn Krondorfer, Men and masculinities in Christianity and Judaism: A critical reader. London, UK: SCM Press, 421-436.

- 2010. Male confessions: Intimate revelations and the religious imagination. Stanford, California: Stanford University Press.

Landman, C. 1998. African women's theology. Hatfield, Pretoria: Van Schaik.

Larson, Jennifer. 2004. Paul's masculinity, JBL 123 (Spring 2004):85-97.

Loader, William. 2004. The Septuagint, sexuality, and the New Testament: Case studies on the impact of the LXX in Philo and the New Testament. Grand Rapids, MI: Eerdmans.

MacDonald, Margaret Y. 1996. Early Christian women and pagan opinion: The power of the hysterical woman. Cambridge: Cambridge University Press.

Marchal, Joseph A. 2008. The politics of heaven: Women, gender, and empire in the study of Paul. Minneapolis: Fortress Press.

Martin, Dale B. 1995. The Corinthian body. New Haven: Yale University Press.

- . 1995. Heterosexism and the interpretation of Romans 1:18-32, Biblical Interpretation 3:332-355.

-. 2006. Sex and the single Savior: Gender and sexuality in Biblical interpretation. Louisville: Westminster John Knox Press.

Martin, Joan. 1995. A womanist investigation of the work ethic of antebellum enslaved women, 1830-1865. In Jacquelyn Grant (Ed.), Perspectives on womanist theology. Atlanta, GA: ITC Press, 5-24.

Martin, Troy W. 2004. Paul's argument from nature for the veil in 1 Corinthians 11:13-15: A testicle instead of a head covering, JBL 123 (Spring 2004):75-84.

Matthews, Shelly, Briggs Kittredge, Cynthia and Johnson-DeBaufre, Melanie. 2003. Walk in the ways of wisdom. In Shelly Matthews, Cynthia Briggs Kittredge and Melanie Johnson-Debaufre (Eds), Walk in the ways of wisdom: Essays in honor of Elisabeth Schüssler Fiorenza. Harrisburg, PA: Trinity Press International, 1-14.

May, Alistair Scott. 2004. The body for the Lord: Sex and identity in 1 Corinthians 57. New York: T\&T Clark International.

Mayordomo, Moisés. 2008. Konstruktionen von männlichkeit in der Antike und der Paulinischen Korintherkorrespondenz, Evangelische Theologie 68(2):99-115.

Merkle, Benjamin L. 2006. Paul's arguments from creation in 1 Corinthians 11:8-9 and 1 Timothy 2:13-14: An apparent inconsistency answered, JETS 49 (3 September):527-548.

Moore, Stephen D. 1996. God's gym: Divine male bodies of the Bible. New York, NY: Routledge.

- 2001. God's beauty parlor and other queer spaces in and around the Bible. Stanford, California: Stanford University Press. 
Moore, Stephen D. and Anderson, Janice Capel. 1998. Taking it like a man: Masculinity in 4 Maccabees, JBL 117(2):249-273.

Mount, Christopher. 2005. 1 Corinthians 11:3-16: Spirit possession and authority in a non-Pauline interpolation, Journal of Biblical Literature 124 (Summer):313-340.

Murphy-O' Connor, Jerome. 1976. The non-Pauline character of 1 Corinthians 11:216, JBL 95:615-621.

-. 1980. Sex and logic in 1 Corinthians 11:2-16, CBQ 42:483.

-. 1988. 1 Corinthians 11:2-16 once again, CBQ 50 (2 April):265-274.

Oakley, Ann. 1972. Sex, gender and society. London: Temple Smith.

Odell-Scott, David. 1983. Let the women speak in church: An egalitarian interpretation of 1 Cor 14.33b-36, Biblical Theology Bulletin 13.3:90-93. Scholars Press.

—. 1991. Re-plying the gender hierarchy. In A post-patriarchal Christology. Atlanta: Scholars Press, 179-183.

Oduyoye, Mercy Amba. 1998. African women's hermeneutics. In Simon Maimela and Adrio König (Eds), Initiation into theology: The rich variety of theology and hermeneutics. Hatfield, Pretoria: JL van Schaik Publishers, 359-372.

Økland, Jorunn. 2004. Women in their place: Paul and the Corinthian discourse of gender and sanctuary space, Journal for the Study of the New Testament Supplement Series. London: T \& T Clark International.

Osiek, C. and Balch, D. 2003. Early Christian families in context. Grand Rapids: Eerdmans.

Osiek, C. and Madigan, K. 2005. Ordained women in the early church: A documentary history. Baltimore: John Hopkins University Press.

Osiek, Carolyn, MacDonald, Margaret Y. and Tulloch, Janet H. 2006. A woman's place: House churches in earliest Christianity. Minneapolis: Fortress.

Oster, Richard. 1988. When men wore veils to worship: The historical context of 1 Corinthians 11:4, NTS 34:481-505.

Paige, Terence. 2002. The social matrix of women's speech at Corinth, Bulletin for Biblical Research 12(2):217-242.

Penner, Todd and Vander Stichele, Caroline. 2005. Unveiling Paul: Gendering ethos in 1 Corinthians 11:2-16. In Thomas H. Olbricht and Anders Eriksson (Eds), Rhetoric, ethic, and moral persuasion in Biblical discourse: Essays from the 2002 Heidelberg Conference. New York \& London: T \& T Clark, 214-237.

Phiri, Isabel Apawo. 2000. Stand up and be counted. In Denise Ackermann, Eliza Getman, Hantie Kotze and Judy Tobler (Eds), Claiming our footprints: South African women reflect on context, identity and spirituality. Stellenbosch; Cape Town: Milano Printing, 145-160.

-. 1997. Women, Presbyterianism and patriarchy: Religious experience of Chewa women in Central Malawi. Blantyre, Malawi: Christian Literature Association in Malawi.

Plaskow, Judith and Christ, Carol P. 1989. Weaving the visions: New patterns in feminist spirituality. San Francisco, California: Harper and Row.

Pomeroy, Sarah B. 1975. Goddesses, whores, wives, and slaves: Women in classical antiquity. New York, NY: Schocken Books.

Pui-lan, Kwok. 2005. Postcolonial imagination \& feminist theology. Louisville, Kentucky: Westminster John Knox Press. 
Richardson, Laurel Walum. 1981. The dynamics of sex and gender: A sociological perspective. Boston: Houghton Mifflin Company.

Robbins, Vernon K. 2002. The rhetorical full-turn in Biblical interpretation and its relevance for feminist hermeneutics. Paper presented at the International Society of Biblical Literature meeting in Berlin, July 20, 2002.

Ruether, Rosemary Radford (Ed.). 1974. Religion and sexism: Images of women in the Jewish and Christian traditions. New York: Simon and Schuster.

-. 2005. Integrating ecofeminism, globalization, and world religions. Lanham, Maryland: Rowman \& Littlefield.

Satlow, Michael L. 1994 "They abused him like a woman": Homoeroticism, gender blurring, and the rabbis in late antiquity, Journal of the History of Sexuality 5 (1 July):1-25.

Schneider, Laurel C. 2009. Homosexuality, queer theory, and Christian theology. In Björn Krondorfer, Men and masculinities in Christianity and Judaism: A critical reader. London, UK: SCM Press, 63-76.

Schüssler Fiorenza, Elisabeth. 1984a. Bread not stone: The challenge of feminist biblical interpretation. Boston: Beacon Press.

-. 1984b. In memory of her: A feminist theological reconstruction of Christian origins. New York: Crossroad Publishing Company.

- 1985. Remembering the past in creating the future: Historical critical scholarship and feminist biblical interpretation. In Yarbro A. Collins (Ed.), Feminist perspectives on biblical scholarship. Atlanta: Scholars Press.

-. 2000. Paul and the politics of interpretation. In Richard A. Horsley (Ed.), Paul and politics: Ekklesia, Israel, imperium, interpretation: Essays in honor of Krister Stendahl. Harrisburg, PA: Trinity Press International, 40-57.

- 2001. Wisdom ways: Introducing feminist biblical interpretation. Maryknoll: NY: Orbis.

-. 2007. The power of the word: Scripture and the rhetoric of empire. Minneapolis, MN: Fortress Press.

Scroggs, Robin. 1983. The New Testament and homosexuality: Contextual background for contemporary debate. Philadelphia: Fortress Press.

Segovia, Fernando F. 2003. Looking back, looking around, looking ahead: An interview with Elisabeth Schüssler Fiorenza. In Fernando F. Segovia (Ed.), Toward a new heaven and a new earth: Essays in honor of Elisabeth Schüssler Fiorenza. Maryknoll, NY: Orbis, 1-32.

Shapiro, Susan. 2003. (En)Gendering Jewish philosophy. In Fernando F. Segovia (Ed.), Toward a new heaven and a new earth: Essays in honor of Elisabeth Schüssler Fiorenza. Maryknoll, NY: Orbis, 516-536.

Stegemann, Ekkehard, and Stegemann, Wolfgang. 1999. The Jesus movement: A social history of its first century. Minneapolis: Fortress Press.

Stoller, R. 1968. Sex and gender. New York: Aronson.

Sugirtharajah, R.S. 2003. The end of biblical studies? In Fernando F. Segovia (Ed.), Toward a new heaven and a new earth: Essays in honor of Elisabeth Schüssler Fiorenza. Maryknoll, NY: Orbis, 133-140.

Tamez, Elsa. 2006. Through her eyes: Women's theology from Latin America. Eugene, Oregon: Wipf \& Stock. 
Taylor, Joan E. 2003. Jewish women philosophers of first-century Alexandria: Philo's "therapeutae" reconsidered, $J B L$. Oxford: Oxford University Press.

Thiselton, Anthony C. 2000. The First Epistle to the Corinthians: A commentary on the Greek text. Grand Rapids, Michigan: The Paternoster Press.

Thompson, Cynthia L. 1988. Hairstyles, head-coverings, and St. Paul: Portraits from Corinth, BA 51:99-115.

Trompf, G.W. 1980. On attitudes toward women in Paul and the Paulinist literature:1 Corinthians 11:3-16 and its context, CBQ 196-215.

Tucker, Mary Evelyn. 2007. Women, religion, and the challenge of the ecological crisis. In Rosemary Radford Ruether (Ed.), Feminist theologies: Legacy and prospect. Minneapolis, MN: Fortress, 129-138.

Vander Stichele, Caroline and Penner, Todd. 2005a. Mastering the tools or retooling the masters? The legacy of historical-critical discourse. In Caroline Vander Stichele and Todd Penner (Eds), Her master's tools? Feminist and postcolonial engagements of historical-critical discourse. Atlanta: Society of Biblical Literature, $1-30$.

- 2005b. Paul and the rhetoric of gender. In Caroline Vander Stichele and Todd Penner (Eds), Her master's tools? Feminist and postcolonial engagements of historical-critical discourse. Atlanta: Society of Biblical Literature, 287-310.

Vorster, Johannes. 1994. The Context of the Letter to the Romans: A Critique on the Present State of Research. Neotestamentica 28 (1): 127-45.

Walker, Alice. 1983. In search of our mother's gardens. New York, NY: Harcourt Brace Javonich.

Walker, William O. Jr. 1975. 1 Corinthians 11:2-16 and Paul's views regarding women, JBL 94:94-110.

- 1983. The "Theology of woman's place" and the Paulist tradition. In Mary Ann Tolbert (Ed.), Semeia 28:101-112: The Bible and feminist hermeneutics (Vol. 28), Society of Biblical literature. Atlanta: Scholars Press.

- . 1989. The vocabulary of 1 Corinthians 11:3-16: Pauline or non-Pauline?, Journal for the Study of the New Testament 35 (February):75-88.

Wanamaker, Charles A. (2003a). "By the power of God": Rhetoric and ideology in 2 Corinthians 10-13. In David B. Gowler, L. Gregory Bloomquist and Duane F. Watson (eds.), Fabrics of discourse: Essays in honor of Vernon K. Robbins. Harrisburg, PA: Trinity Press International, 194-221.

Weiss, Johannes. 1977. Der Erste Korintherbrief. Göttingen: Vandenhoeck \& Ruprecht.

Winkler, John. 1990b. The constraints of desire: The anthropology of sex and gender in ancient Greece. New York, NY: Routledge.

Winter, Bruce W. 2003a. Roman wives, Roman widows: The appearance of new women and the Pauline communities. Grand Rapids, MI: William B. Eerdmans.

Wire, Antoinette Clark. 1990b. The Corinthian women prophets: A reconstruction of Paul's rhetoric. Minneapolis: Fortress Press.

Witherington, Ben III. 1992. Women and the genesis of Christianity. Cambridge: Cambridge University Press.

-. 1995. Conflict and community in Corinth: A socio-rhetorical commentary on 1 and 2 Corinthians. Grand Rapids, MI: Eerdmans. 